\title{
The representation of Alistair Maclean's life as reflected in south by Java Head: a biographical study
}

\author{
Hafida Amalia a,1,* \\ ${ }^{a}$ Litelature English Departement Ahmad Dahlan \\ ${ }^{1}$ hafida@com.uad.ac.id*; \\ * corresponding author
}

Article history

Received 01-09-2020

Revised 23-10-2020

Accepted 04-11-2020

\section{Keywords}

South by Java Head

World War II

Biographical Approach

\begin{abstract}
This undergraduate thesis research aims to understand and inform the period of World War II experienced by the author Alistair MacLean from a military perspective rather than from a war leader. Because of this, the authors consider this research interesting because it can find the similarity and differences between the novel and Alistair MacLean.The writer applies the biographical approach as the basic of the analysis. The method of this analysis systematically used qualitative methods in compiling this research as the techniques - library data sources, journal article, internet and all books dealing with this research, and the main textual data in South by Java Head. The results of this analysis indicate that in the military life of the war during World War II that seemed disciplined that they made a lifelong commitment to, it turns out there are still those who consciously committed acts of violation; similarity: Japanese Cruelty, Deadly Weapons ect, differences: The Deal Punishment. But there are also some positive knowledge, especially for readers.
\end{abstract}

\section{Introduction}

A. Background of Choosing the Subject

Everyone has a desire to improve his or her knowledge. One of the activities to increase knowledge is by reading. We will get a lot of information through reading. One of reading materials is literary work, such as poem, novel, short story and drama. Such literary works mentioned above are the products of creative compositions of an author. Each of the writers creating a certain literary work owns a different life background. He or she may be a person from high class, middle class or even lower class. (AMBARWATI, 2007) (https://lib.unnes.ac.id/788/1/1904.pdf).

Based on the explanation above, there is a statement clarifying that the life background of an author will influence the literary work he or she composed. According to Rene Wellek and Austin Warren "the main reason of literary work given birth is the composer himself or herself namely an author. That is why the explanation of personality and the author's life is the oldest and established method in the literary work study". Furthermore, it is also said that biography explains and clarifies the truth composition process of literary work (S. Wellek, 2017).

Based on the previous explanation, "Biography is detailed description or account of someone's life. More than a list of basic facts (education, work, relationships and death), biography also potrays the subject's experience of those events. Unlike a profile or curriculum vitae (resume), a biography presents the subject's life story, highlighting various aspects of his or her life, including intimate details of experience, and may include an analysis of the subject's personality. Biographical 
approach examines the literary work in relation to the author's life. And often a particular poem or song is subject to this kind of analysis simply by nature or its material in relation to the background of the author's personal experience. Or simply we can say, Biographical Approach is an approach used to understand and comprehend a literary work by studying deeper about the author's life" (Reaske, 1972).

Alistair MacLean is a great novelist with a unique life background and the education he got influenced to wrote experience novel that he later put to good literary use. Foremost, the writer antusiastic with the object "war story" of this novel that brings character from many countries in a small boat where they face wrath of both nature and war time from him personal experience in the Royal Navy during the World War II. Secondly, MacLean's novel are highly dramatic setting, absence of sex and most are short on romance. Thirdly, many his novels occur at sea so his knowledge of maritime topics shines through his descriptions of boats, nautical maneuvers and sometimes cruel sea. (https://www.sagepub.com/sites/default/files/upm-binaries/43454_10.pdf)

According to Christopher Reaske (1966), "Biography is detailed description or account of someone's life. More than a list of basic facts (education, work, relationships and death), biography also potrays the subject's experience of those events. Unlike a profile or curriculum vitae (resume), a biography presents the subject's life story, highlighting various aspects of his or her life, including intimate details of experience, and may include an analysis of the subject's personality. Biographical approach examines the literary work in relation to the author's life. And often a particular poem or song is subject to this kind of analysis simply by nature or its material in relation to the background of the author's personal experience. Or simply we can say, Biographical Approach is an approach used to understand and comprehend a literary work by studying deeper about the author's life".

The writer will discuss about biography of Alistair Maclean's on South by Java Head. MacLean's novel are highly dramatic setting, absence sex and most are short on romance because MacLean thought that such diversions merely serve to slow down the action. Many of the adventure in his novels occur at sea and several of his best known works are set during World War II.

Alistair MacLean is a great novelist with a unique life background. The environment around him and the education he got influenced to wrote experience novel that he later put to good literary use. Foremost, the writer antusiastic with the object "war story" of this novel that brings character from many countries in a small boat where they face wrath of both nature and war time from him personal experience in the Royal Navy during the World War II. Secondly, South by Java Head is the third novel known as a popular author on 20th Century. Alistair MacLean as a author that wrote twenty nine bestselling in the world was an enormously popular Scots novelist, screenplay writer and short story writer best known for The Guns of Navarone and Ice Station Zebra. Thirdly, his knowledge of maritime topics shines through his descriptions of boats, nautical maneuvers and sometimes cruel sea. (http://articles.latimes.com/1987-02-03/news/mn-750_1_book-deals)

There are many books by MacLean's. They are: H.M.S Ulysses (1955), The Guns of Navarone (1957), South By Java Head (1958), The Secret Ways (1959), The Last Frontier (1959), Night Without End (1960), Fear Is The Key (1960), The Dark Crusader (1961), The Golden Rendezvous (1962), The Satan Bug (1962), Ice Station Zebra (1963), When Eight Bells Toll (1966), Where Eagles Dare (1967), Puppet On A Chain (1969), Caravan to Vaccarès (1970), Bear Island (1971), The Way to Dusty Death (1973), Breakheart Past (1974), Circus (1975), The Golden Gate (1976), Seawitch (1977), Goodbye California (1978), Athabasca (1980), Partisans (1982), San Andreas (1984), The Lonely Sea (1985) the collection of short stories; two stories added in 2009 and Santorini (1986). (http://www.freshfiction.com/author.php?id=22458)

\section{Theorotocal Framework}

In analyzing Many qualitative research methods can be used in the process investigation of studied objects. They have typical and different ways in the process and adaptation to their problem research. This thesis will be presented with five traditions which may often be used as a discourse for the research process. The five traditions are biography, phenomenology, grounded theory, ethnography, and case studies.

Hafida Amalia (The Representation of Alistair Maclean's life as reflected in south by java head: a biographical study) 
(https://research-methodology.net/research-methods/data-analysis/qualitative-data-analysis/)

Biography pertains to the social reality that influences the course of an individual's life. On the other hand, it pertains to those processes and events that a person wishes and is able to tell about, that is, his or her subjective experience and emotions (Schütze \& Schütze, 2019).

According to (R. Wellek, 1978), biographical models are considered the oldest approach. The biographical approach is a systematic study of the process of creativity. The creator's subject is regarded as the origin of literature, the meaning of a literary work is thus relatively the same as the intent, intention, message, and even certain purposes of the author. Research must include biographies, letters, important documents of the author, photographs, and even direct interviews with the author. Literary works in turn are identical with curriculum vitae, author's statements are regarded as truth, biography subordinates the work. Therefore, the biographical approach is actually part of historical writing, as historiography. (http://syahrul-net.blogspot.com/2012/12/jenis-jenispendekatan-sastra-dan.html)

As a member of the community, the author by itself is more successful in describing the community in which he lives, the environment he truly experiences in real life. Therefore, as well as scientists from other disciplines in expressing social symptoms, the author is also considered necessary to conduct a kind of 'research' which is then interpretatively imaginatively elevated into artwork.

Therefore, in relation to creative activities there are three types of authors, namely: (1) An author who writes based on direct experience, (2) Authors who compose based on skills in rearranging the elements of storytelling, and, (3)Authors who compose based on the power of imagination. However, the process of creativity is generally based on a combination of these three factors.

Humans, and by the authors themselves, are social beings. Although often rejected, in certain cases biographies are still useful. In literature, the author's biography, not curriculum vitae, helps to understand the creative process, the genesis of art. Biography extends while limiting the analysis process. In social science, biography is generally used in relation to the background of the process of reconstructing facts, helping to explain the thoughts of an expert, such as the ideological system, the scientific paradigm, the worldview, and the general socio-cultural framework that surrounds it. Elmusharaf, Dr. Khalifa. 2012.

(https://www.gfmer.ch/SRH-Course-2012/research-methodology/pdf/Qualitative-data-collectionElmusharaf-2012.pdf)

\section{Method}

It is important to describe the objective of the study. Yet avoid having the ambiguity of the objectives the writer has to specify them, referring to the problem that formulated: To find the similarities and the difference between the novel and Alistair MacLean's Life (Method, 2003).

\section{Results and Discussion}

In this chapter consists of the discussion about the experiences of Alistair MacLean in Royal Navy that have determined by the writer in the previous chapter. The first, the writer will involves the situations that representations of Alistair MacLean's experiences which stated in the novel South by Java Head based on biographical approach. In this second part, the writer will try to find some differences and similarities into a few points, each point will have quotations of dialogue, so the discussion will be clear and easy to be understood.

\subsection{Difference of MacLean's Experiences in Royal Navy with The Novel}

What MacLean have done is a serious offense by changing his name. We can see in this paragraph: "What you have done is a serious offense. I will personally recommend that you be put to death. But there are some of us who believe that you are disguising because of your very desire to serve your country, and therefore your life is conditionally forgiven". (Ch. 14 P. 217) "No one can know the existence of a pilot who disguises his name because it will tarnish the military". (Ch. 14 P. 
217). "Then, today, you are dead. Not really dead, but your family will be notified if you are killed on a military mission and a funeral will be done for you, your name will be crossed out and you will no longer be in this world". (Ch. 14 P. 217) This sentence shows the punishment that Maclean gets is that his name is considered dead. But in reality, MacLean is still alive. He just never meet his parents stated by Robert a lee (Lee \& Rid, 2014).

\subsection{Similarities of MacLean's experiences in Royal Navy with The Novel}

The Imperial Japanese Army or IJA, literally Army of the Greater Japanese Empire, was the official ground-based armed force of the Empire of Japan, from 1871 to 1945. (https://visitpearlharbor.org/category/history/attack-of-pearl-harbor/japanese-forces/imperialjapanese-navy/). We can see in this paragraph:

Choking, dense, impenetrable, the black smoke lay pall-like over the dying city. Every building, every office-block and house, the intact and the bomb-shattered alike, was invested by it, swathed in the dark anonymity of its gently swirling cocoon. Every street, every alley, every dock-side basin was full of it, drowned by it. It lay everywhere, sulphurous and evil, scarcely moving in the soft airs of the tropical night. (Ch. 1 P. 5)

"Fear and dismay, sickness and despair - such were the things that coloured and dominated the entire existences of the wandering band of soldiers, the little boy and the nurses, and tens of thousands of others on that midnight of 14th February, 1942, as the exultant, all-conquering Japanese crouched outside the last defences of the city, waiting for the dawn, waiting for the assault, the bloodbath and the victory that must inevitably come". (Ch. 1 P. 11)

In paragraph above, there are an illustration of what happened during World War II. Alfred Tennyson attributed "Viroma" determination to persevere to the last, in "Viroma" to his own resolute choice in favor of life and survival on the traumatic news of the death of friend, soul-mate, and intending future brother-in- law (Hallam \& Wignall, 1999). This is the worst history and we can only see the people who experienced the incident directly. Massive bombing within a few hours left the city destroyed. Smoke, lack of water, and fire. Everything is burning, even bricks. It feels like hell, hell on Earth. It is proved in the following paragraph:

"Something struck him with cruel, numbing force against his knee-caps. The boat, drifting upside down. He somersaulted in mid-air, struck his shoulder against the keel, landed flat on his back on the water on the other side with an explosive smack that drove all the breath out of his body, then was on his way again, propelled by a fear and a nameless anger such as he had never known before. The pain in his chest and his legs was another turn of the rack for every step he took, but he drove himself on remorselessly as if the fire in his legs and his body's gasping demands for air simply did not exist". (Ch. 12 P. 185)

"The heat inside struck at him with the physical impact of a violent blow, he could feel it engulf him, wash over him in a great wave of burning pain. The superheated air, starved now of its lifegiving oxygen, seared down into his lungs like fire itself. He could smell his hair singeing almost immediately, and the tears flooded into his eyes and threatened to blind him." (Ch. 14 P. 215)

A chilling, realistic story that drew on his military experiences and was compared favorably by reviewers (at least those who did not receive their paychecks from the Daily Record) with Herman Wouk's The Caine Mutiny (1952) mention by J. Kingston Pierce on October 1st, 2013.

\subsection{Military Live}

Many interesting stories during World War II. Stated by James Nohrnberg (Nohrnberg, 2017), desiring to take part in the progress of the country, a young MacLean was twenty years old, he never thought left this city or his family, he did not know about war and struggle. But his sense of patriotism was mixed between the fear of the harshness of a soldier's life and pride in finally joining the military. We can see in this description: That's the first time if he realizes the change that happened in himself. He was not a man who is little more serious than youth in the small city. He realizes as well as interested in the gemerical voices in the radio that signs Japanese victory news in the asis, specially South Asia. (Ch. 1 P. 16) 
World War II forced many people to take up arms. Not only soldiers, but many civilians who participated in the battlefield. One of them is Alistair Stuart MacLean. A military might win a war when equipped with deadly weapons or even nuclear power. The problem is not just a matter of strategy, there are many stories about humans who face war. Sometimes, patience, patriotism, and emotion are involved when surprising things happen to them. The terror and destruction faced by millions of people during the outbreak of World War II was indeed unimaginable. This terrible story became the history of man kind and we can only see it through eyewitnesses of those who experienced the incident directly. Those who lived in the war era and had to be trapped by deadly conflict in history.

A military learns the lessons of life through harsh experiences. One of them when an enemy attacks can came any time, when off guard or even when busy, even as implied in the phrase "so Willie Loon's hands move up and down, in staccato" and the ship is still controlled by Willie Loon. We can see in this paragraph: "And so Willie Loon's hand moved up and down, up and down, in the staccato, off-beat rhythm of the trained operator, triggering off the key, sending the same call over and over again: S.O.S., enemy air attack, $0.45 \mathrm{~N}, 104.24 \mathrm{E}$, on fire: S.O.S., enemy air attack, $0.45 \mathrm{~N}$, 104.24 E, on fire: S.O.S. .." (Ch. 3 P. 34).

As a military, bombing incident is not the first time happened to MacLean and his friends. Stated by James A. Winnefeld, it is a story of survival and quiet courage. It is a classic from the perspective of World War II Axis opponent. We can see in this discussion below: "We, a number of tough fighters, bombarded bombs by fascist aircraft, attacked by enemy tanks, were shot by merciless mortar and German artillery. Shots from machine guns and automatic rifles did not stop for a minute. We lack ammunition, food and water. There is no air due to grenade explosions". (Ch. 2 P. 22).

Through this smoke-blackened door a man cried out from time to time, a cry not of pain but of anguished memory lacerating a darkening mind; there were whimpers, too, from other badly wounded men, again not moans of pain; the Eurasian nursing sister had with her all the drugs and sedatives she required, not pain but just the feeble, aimless murmur of dying men. Now and again a woman's voice could be heard, soothing, consoling, the soft sound of it punctuated from time to time by the deep angry rumble of a man. But mostly it was just the husky undertones of sick men and, very occasionally, the quivering indrawn breaths, the lost and lonely wailing of a little child. (Ch. 3 P. 46).

"The Viroma was now thrusting north dead in the eye of the gale-force wind, and the heavy driving rain, strangely cold after the heat of the day, was sweeping almost horizontally fore and aft across the decks and the bridge, numbing his face with a thousand little lances, filling his eyes with pain and tears. Even with eyes screwed tight to the narrowest slits, the rain still stung and blinded: they were blind men groping in a blind world and the end of the world was where they stood." (Ch. 3 P. 49).

In this paragraph above, inevitably, the natural world joins in the agony as a typhoon bears down on ship. First the escape through the ruined city; then the defeat of no boat being there, the reprieve of a rowboat arriving and escape to the Kerry; then murderous attack by Jap airplanes; then rescue by the Viroma in the midst of a fierce typhoon; then renewed attack by Jap planes which devastate the tanker killing most of its crew, the few survivors managing to escape into a lifeboat. And then the opposite of the tropical typhoon - they are completely becalmed under a blistering tropical sun, for days on end as the food and then the water slowly run out, until crew members go literally mad, drinking sea water and then throwing themselves overboard to die (Sinek, 2013).

\subsection{Weapons}

It is not easy for teenagers to become military, not even three months, some of them even have to die because they accidentally stepped on mines, or damaged components of mines which then made them explode. We can see in this paragraph:

"All three men were hurt, and badly: all of them had lost blood, Telak most of all, and no competent doctor would have hesitated to immobilise any of the three in hospital: but they ran all the way to Bantuk, across impossible, energy-sapping, heart-breaking terrain, never once breaking down into a walk. They ran with their hearts pounding madly under the inhuman strain, leaden legs fiery 
with the pain of muscles taxed far beyond endurance, chests rising and falling, rising and falling as starving lungs gasped for more and still more air, the sweat running off their bodies in streams." (Ch.15 P. 234).

He tried to wake up. But every time he moved his body, the pain he felt made him unconscious. The following days were mostly spent sleeping. More and more days the pain he felt while moving was getting less. Finally, thanks to his will, it takes less than two weeks to treat his bones and organs and two weeks to make him able to walk again after passing very painful exercises in the rehabilitation room. (Ch. 8 P. 123).

Refer to Simon (2013), the wartime setting allows free rein for MacLean's distinguishing feature, Extremity: physical and psychological extremity. This is the state of the shell-shocked nurses, exhausted soldiers, the injured and wounded aboard the little freighter Kerry Dancer, or the experience-hardened captain and crew of the tanker Viroma who steer to their rescue, even before they are attacked by the Japanese - and the narrative propels them through ordeal after ordeal, far beyond the bounds of plausibility.

The dream of everyone in this world is peace and prosperity. To be able to realize that need of a concern and awareness to be able to join and fight together. The ways which it travels are diverse and even warcan not be avoided anymore. We can see in this paragraph: "I forbid you to go, Sayuri", his mother exclaimed."I have sacrificed my son for the sake of this nation, do I have to sacrifice my daughter too?".(Ch. 4 P. 52).

Sadness is not only because boys become a military, but when girls also want to contribute to their country as a nurse.

\section{Conclusion}

From the analysis in the previous chapter, the writer can conclude that there is an knowledge from Alistair MacLean's experience in the Royal Navy. This novel is supported by the background of MacLean's life which is summarized into similarities and the difference experienced by MacLean are as follows;

Similarities: World War II, Japanese Cruelty, Military Life, Deadly Weapons, As a Plane Fighter, Japanese Prisoner and The Deal Punishment. Difference: The Deal Punishment by changing his name is that his name is considered dead, not really dead, because in reality MacLean is still alive.

South by Java Head had a great emotional impact to readers how Japanese Cruelty to th?eirs enemies as heartless killing machines and frequently referring to them as "those inhuman devils". Including the last, it was a brilliant adventure, desperate people trying to reach Australia by sea from Singapore. Elements of tension - when will be attacked and how to overcome them. The surviving protagonists defeat all obstacles. Obviously, you will also be made to guess who will be a traitor, there may be one or more.

However, the point is, whether the reader is contemplated if the event is possible, the reader will definitely be happy to read this book. This book is highly recommended for those who are on the same "boat" as I am in terms of interest. 


\section{References}

AMBARWATI, A. (2007). The effectiveness of antibacteria substances from neem seeds (Azadirachta indica) to impede the growth of Salmonella thyposa and Staphylococcus aureus. Biodiversitas, Journal of Biological Diversity. https://doi.org/10.13057/biodiv/d080415

Hallam, A., \& Wignall, P. B. (1999). Mass extinctions and sea-level changes. Earth Science Reviews. https://doi.org/10.1016/S0012-8252(99)00055-0

Lee, R. M., \& Rid, T. (2014). OMG Cyber! The RUSI Journal. https://doi.org/10.1080/03071847.2014.969932

Method, S. (2003). Teacher Guide. Reproduction.

Nohrnberg, J. (2017). Milton and the divisions of history. Modern Language Quarterly. https://doi.org/10.1215/00267929-3898224

Reaske, C. R. (1972). The Devil and Jonathan Edwards. Journal of the History of Ideas. https://doi.org/10.2307/2709061

Schütze, F., \& Schütze, F. (2019). Biographieforschung und narratives Interview. In Sozialwissenschaftliche Prozessanalyse. https://doi.org/10.2307/j.ctvdf09cn.6

Sinek, S. (2013). Start with why. TED Talk.

Wellek, R. (1978). The New Criticism: Pro and Contra. Critical Inquiry. https://doi.org/10.1086/447958

Wellek, S. (2017). A critical evaluation of the current "p-value controversy." Biometrical Journal. https://doi.org/10.1002/bimj.201700001 